\title{
The Effect of Sulfate Attack on Physical Properties of Concrete
}

\author{
Pooja Kanaujia, Rajiv Banerjee, Syed Mohammad Ashraf Husain, Sabih Ahmed
}

\begin{abstract}
The effects of different concentrations of sulfate for erosion age on compressive strength, flexural strength, weight analysis, density loss and visual appearances for concrete specimens of different grades were investigated. Experimental studies were carried out on different grades of concrete (M-25, M-30 and M-35). Concrete specimens were immersed in different concentration of sulfate solution i.e. $4.0 \mathrm{pH}, 5.0 \mathrm{pH}$ and $6.0 \mathrm{pH}$. Reduction in compressive strength loss was noticed when the grade of concrete is increased from M-25 to M35. The results of weight analysis and density analysis also confirm the compressive strength loss and flexural strength. Discoloration of concrete was noticed on the concrete blocks when left immersed in sulfate solution at $4.0 \mathrm{pH}$, $5.0 \mathrm{pH}$ and $6.0 \mathrm{pH}$ for 75days and 90days. It appeared like flakes of concrete and resembled like mold growth.
\end{abstract}

Keywords: Compressive Strength Loss, Weight Analysis, Sulfates Attack, Concrete, pH Concentration.

\section{INTRODUCTION}

The effects of sulfate on physical and chemical characteristics require complex procedures to study in detail. The disintegration of concrete depends on the cementious material used. [1] The sulfate attack can result in the generation of expansive products and the decomposition of hydration products of cement [2]. Concrete, as an artificial porous material also suffers from degradation caused by salt crystallization. For the past few decades, most laboratories have studied the durability of concrete exposed to sulphates. Compound sulphate assault includes synthetic response between sulphate particles and concrete hydration items or the principle segments of concrete. In the case of chemical sulfate attack, sulphates of sodium, potassium, calcium, or magnesium in soil or dissolved in groundwater or seawater in the vicinity of concrete structures enter concrete, attack the hardened cement paste and increase the potential of deterioration [3,10,23]. Harm of cement because of salt crystallization has been portrayed as an actual salt assault [4]. In recent years, sulfate attack with existing environmental and mechanical factors have attracted the attention of scholars, such as sulfate attack under dryingwetting and heating-cooling environments , frost action, static flexural loading, flexural fatigue loading, static flexural loading and drying-wetting cycles , static flexural loading and freeze- thaw cycles $[6,10,13]$.

Manuscript received on June 11, 2021.

Revised Manuscript received on June 18, 2021.

Manuscript published on July 30, 2021.

* Correspondence Author

Pooja Kanaujia*, M.Tech Scholar of Structural Engineering, Department of Civil Engineering, Integral University, Lucknow (U.P), India.

Rajiv Banerjee, Associate Professor, Department of Civil Engineering, Integral University, Lucknow (U.P), India.

Syed Mohammad Ashraf Husain, Senior Engineer, Department of Civil Engineering, Kanpur (U.P) India

Sabih Ahmed, Associate Professor, Department of Civil Engineering, Integral University Lucknow (U.P), India

(C) The Authors. Published by Blue Eyes Intelligence Engineering and Sciences Publication (BEIESP). This is an open access article under the CC BY-NC-ND license (http://creativecommons.org/licenses/by-nc-nd/4.0/)
Sulfate attack triggers changes to concrete hydration process leading to undesired harmful effects. Decalcification of the $\mathrm{C}-\mathrm{S}-\mathrm{H}$ stage, filtering and decrement of the $\mathrm{pH}$ because of sulfate assault leads to solidify glue corruption. Sulfate attack is a complicated phenomenon affected by many parameters, salt weathering $[7,11]$. Solid constructions may experience the ill effects of sulfate assault, which causes genuine disintegration of the solid and influences the assistance life of the designs. Sulfate particles infiltrate the pores and consequently structure a forceful arrangement, which respond with specific segments of hydrated concrete (calcium hydroxide, hydrated calcium aluminate and AFm stages) to frame ettringite (AFt) and gypsum that instigate extension [8,9]. This can be characterized as a compound response between the sulphate particles, having infiltrated into the solid by an exchange system, and the mineral segments of the solidified concrete glue, principally Tricalcium aluminate [12, 13, and 14]. Ettringite is a hydrated phase, consists of gypsum that expands in due course [15]. External sulfate attack (ESA) on solid components/structures includes a progression of complex decay systems including like substance and actual angles [16 17, 18]. The concrete structures assistance consistently subject to the coupled impact of various ecological factors, for example, freezing-defrosting, carbonation, and forceful specialist entrance and so on. This accelerates the deterioration of durability [22, 24, and 25].

The objective of this work is to evaluate the effect of sulfate on physical properties of concrete like compressive strength, flexural strength, weight analysis, density analysis and visual appearances.

\section{EXPLORATORY EXAMINATION}

\subsection{Material properties}

2.1.1 Cementious material: The Pozzolana Portland cement was used in the experimental study confirming to IS 1489 (part1).The physical properties of these cementious materials are shown in table 1.

Table 1 Physical property of cementious materials

\begin{tabular}{|c|c|c|c|c|c|}
\hline $\begin{array}{c}\text { Physical } \\
\text { propertie } \\
\text { s }\end{array}$ & $\begin{array}{c}\text { Specifi } \\
\text { c } \\
\text { gravity }\end{array}$ & $\begin{array}{c}\text { Finenes } \\
\mathrm{s}\end{array}$ & $\begin{array}{c}\text { Consistenc } \\
\mathrm{y}\end{array}$ & $\begin{array}{c}\text { Initial } \\
\text { settin } \\
\text { g time }\end{array}$ & $\begin{array}{c}\text { Final } \\
\text { setting } \\
\text { time }\end{array}$ \\
\hline Results & 2.88 & $2.5 \%$ & $33 \%$ & $45 \mathrm{~min}$ & $290 \mathrm{~min}$ \\
\hline
\end{tabular}

\subsubsection{Coarse and Fine Aggregate}

Fine aggregate generally consists of natural sand or crushed stone with most particles passing through a $4.75 \mathrm{~mm}$ sieve. Coarse aggregate are any particles greater than $4.75 \mathrm{~mm}$.
Blue Eyes Intelligence Engineering and Sciences Publication (C) Copyright: All rights reserved.

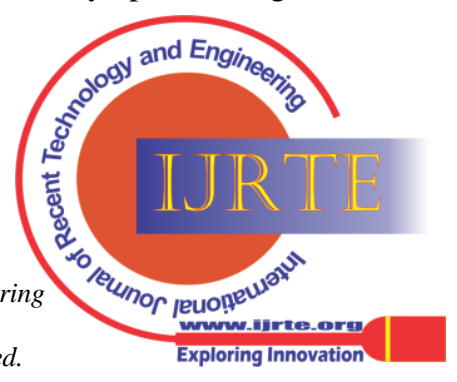


Gravel constitutes the majority of coarse aggregate used in concrete with crushed stone making up most of the remaining aggregate. Physical properties of these aggregates are shown in table 2.

Table 2 Physical properties of fine and coarse aggregates

\begin{tabular}{|l|l|l|l|l|}
\hline $\begin{array}{l}\text { Characteristic } \\
\text { s }\end{array}$ & $\begin{array}{l}\text { Gradin } \\
\text { g zone }\end{array}$ & $\begin{array}{l}\text { Finenes } \\
\text { s } \\
\text { modulu } \\
\text { s }\end{array}$ & $\begin{array}{l}\text { Specifi } \\
\text { c } \\
\text { gravity }\end{array}$ & $\begin{array}{l}\text { Water } \\
\text { absorptio } \\
\text { n }\end{array}$ \\
\hline $\begin{array}{l}\text { Fine } \\
\text { aggregate }\end{array}$ & Zone II & 2.82 & 2.65 & $1 \%$ \\
\hline $\begin{array}{l}\text { Coarse } \\
\text { aggregate }\end{array}$ & $16 \mathrm{~mm}$ & 6.91 & 2.65 & $.15 \%$ \\
\hline
\end{tabular}

\subsection{Mix proportions}

In this study, three different grade of concrete were considered that is M25, M30, and M35. The details of mix proportions are given in table 3.

Table 3 Concrete mix proportion / (kg-m-3).

\begin{tabular}{|c|c|c|c|c|c|}
\hline $\begin{array}{c}\text { Strength } \\
\text { grade }\end{array}$ & Cement & $\begin{array}{c}\text { Fine } \\
\text { aggregate }\end{array}$ & $\begin{array}{c}\text { Coarse } \\
\text { aggregate }\end{array}$ & Water & $\begin{array}{c}\text { Super } \\
\text { plasticizer }\end{array}$ \\
\hline M25 & 348 & 792 & 1095 & 167 & 1.74 \\
\hline M30 & 367 & 770 & 1108 & 161 & 2.93 \\
\hline M35 & 375 & 753 & 1128 & 157 & 3.75 \\
\hline
\end{tabular}

Table4 Compressive Strength

\begin{tabular}{|c|c|c|c|c|c|c|c|c|c|c|}
\hline S.no. & pH & \multicolumn{8}{|c|}{ Compressive strength in N/mm } \\
\cline { 3 - 11 } & value & \multicolumn{2}{|c|}{ M-25 grade of concrete } & \multicolumn{2}{c|}{ M-30 grade of concrete } & \multicolumn{2}{c|}{ M-35 grade of concrete } \\
\hline & & 28 days & 75 days & 90 days & 28days & 75 days & 90 days & 28 days & 75 days & 90 days \\
& & & & & & & & & & \\
\hline $\mathbf{1}$ & 4 & - & 30.87 & 29.66 & - & 35.61 & 33.49 & - & 40.96 & 38.98 \\
\hline $\mathbf{2}$ & 5 & - & 31.25 & 30.53 & - & 36.43 & 35.29 & - & 42.77 & 41.34 \\
\hline $\mathbf{3}$ & 6 & - & 32.00 & 31.82 & - & 37.29 & 36.44 & - & 43.16 & 43.01 \\
\hline $\mathbf{4}$ & 7.5 & 34.00 & 34.80 & 34.83 & 38.10 & 38.78 & 38.80 & 43.35 & 44.10 & 44.15 \\
\hline
\end{tabular}

\section{compressive strength $M-25 \mathrm{~N} / \mathrm{mm} 2$}

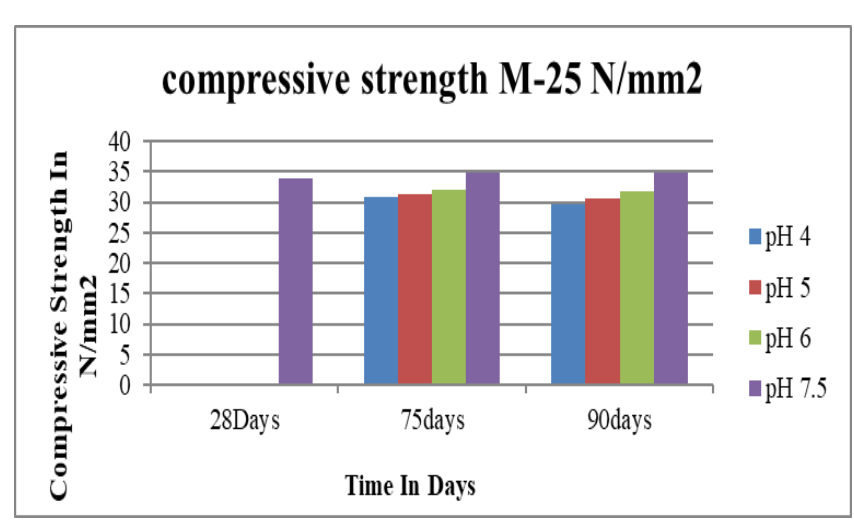

Figure 1 compressive strength

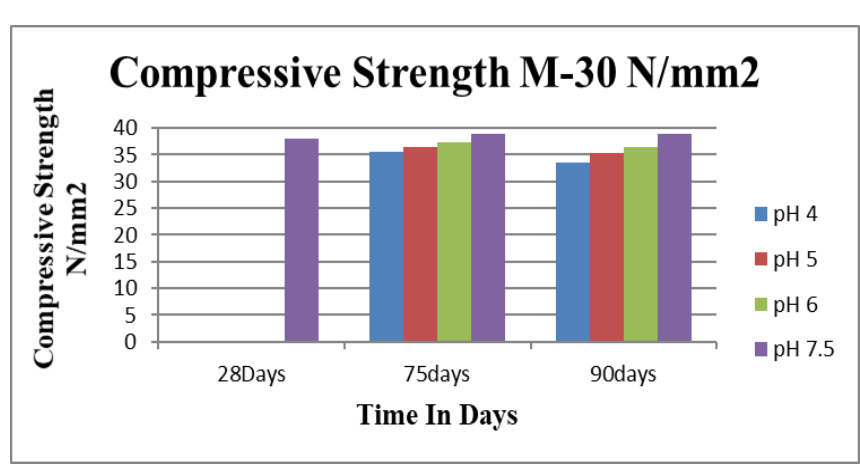

Figure 2 compressive strength

\subsection{Experimental processes}

The test method was carried out in accordance to IS 4562000 and it was used to determine the long term performance and endurance of ordinary concrete. The size of concrete cube was $150 \mathrm{~mm} \times 150 \mathrm{~mm} \times 150 \mathrm{~mm}$ and the same for concrete beam specimen size $100 \mathrm{~mm}$ $\times 100 \mathrm{~mm} \times 500 \mathrm{~mm}$. Concrete mix was prepared for these different grades of concrete M-25, M-30 and M-35. After casting all specimens were then demoulded after 24hour and cured for 28days at a room temperature. Firstly prepared the sulfate solution with different $\mathrm{pH}(4.0 \mathrm{pH}, 5.0 \mathrm{pHand} 6.0 \mathrm{pH})$ in the solution boxes. Thereafter all the concrete specimens were undergone water curing for 28 days and subsequently immersed into sulfate solution. At that point, the solution boxes were covered with the plastic film to guarantee that water was not evaporated. Finally, the specimens were taken out from sulfate solution and dried at room temperature when the erosion age reached to 75days and 90days.

\section{RESULTS AND DISCUSSION}

3.1 Compressive strength analysis

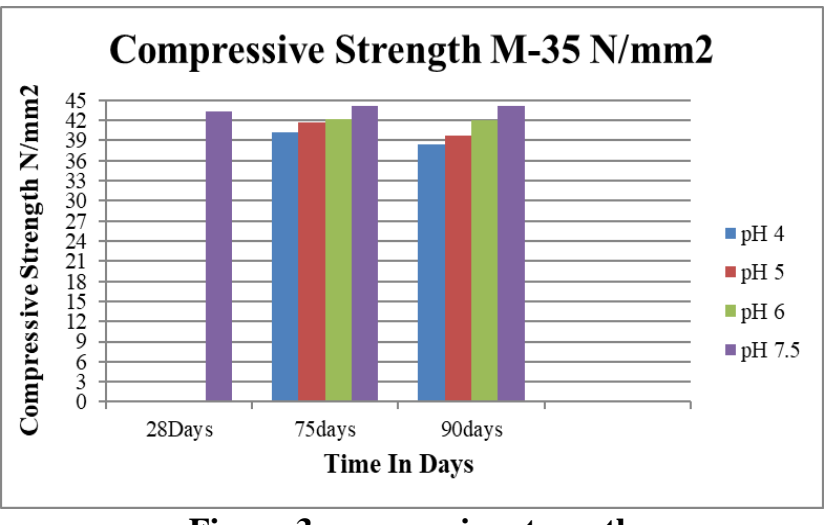

Figure 3 compressive strength

The figures are showing loss of compressive strength in these different grades of concrete M-25, M-30 and M-35 with sulfate concentration. These results were determined after 75days and 90days sulfate exposure at $4.0 \mathrm{pH}, 5.0 \mathrm{pH}$ and $6.0 \mathrm{pH}$. For $\mathrm{M}-25$ grade of concrete, the reduction in compressive strength after 75days of exposure is $11.2 \%$, $10.20 \%$ and $8 \%$ with $\mathrm{pH} 4.0$, pH5.0 and pH6.0 respectively.

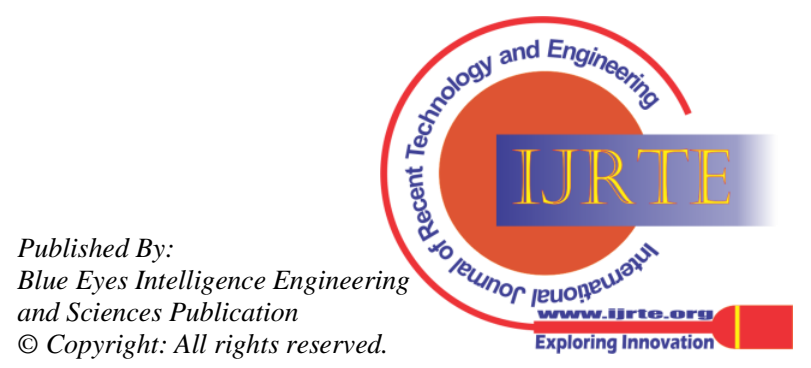


The compressive strength loss after 90days of exposure is $14.8 \%, 12.34 \%$ and $8.6 \%$ with $\mathrm{pH} 4.0$, $\mathrm{pH} 5.0$ and $\mathrm{pH} 6.0$ respectively. For M-30 concrete grade the reduction in compressive strength after 75days of exposure is $8.1 \%, 6 \%$ and $3.8 \%$ with $\mathrm{pH} 4.0$, pH5.0 and pH6.0 respectively.

The reduction in compressive strength loss after 90days of exposure is $13.6 \%, 9 \%$ and $6 \%$ with $\mathrm{pH} 4.0$, pH5.0 and pH6.0 respectively. For M-35 concrete grade mix with sulphate, the compressive strength loss after 75days of exposure is $7.1 \%, 3 \%$ and $2.1 \%$ with $\mathrm{pH} 4.0$, pH5.0 and pH6.0 respectively. The compressive strength loss after 90days of exposure is $11.7 \%, 63 \%$ and $4.8 \%$ with $\mathrm{pH} 4.0$, pH5.0 and pH6.0 respectively. The strength loss of specimen may be attributed to the internal pressure caused by the sulphate.

\subsection{Weight analysis}

Table5 weight analysis

\begin{tabular}{|c|c|c|c|c|c|c|c|c|c|c|}
\hline \multirow{3}{*}{ S.no. } & \multirow{3}{*}{$\begin{array}{c}\mathrm{pH} \\
\text { value }\end{array}$} & \multicolumn{9}{|c|}{ Weight analysis in $\mathrm{kg}$} \\
\hline & & \multicolumn{3}{|c|}{ M-25 grade of concrete } & \multicolumn{3}{|c|}{ M-30 grade of concrete } & \multicolumn{3}{|c|}{ M-35 grade of concrete } \\
\hline & & 28days & 75days & $\begin{array}{c}\text { 90day } \\
\text { s } \\
\end{array}$ & 28days & 75days & 90days & 28days & 75days & 90days \\
\hline 1 & 4 & - & 8.129 & 8.072 & - & 8.139 & 8.160 & - & 8.245 & 8.143 \\
\hline 2 & 5 & - & 8.185 & 8.113 & - & 8.196 & 8.273 & - & 8.298 & 8.287 \\
\hline 3 & 6 & - & 8.231 & 8.200 & - & 8.213 & 8.292 & - & 8.312 & 8.354 \\
\hline 4 & 7.5 & 8.263 & 8.273 & 8.275 & 8.361 & 8.365 & 8.367 & 8.441 & 8.443 & 8.445 \\
\hline
\end{tabular}

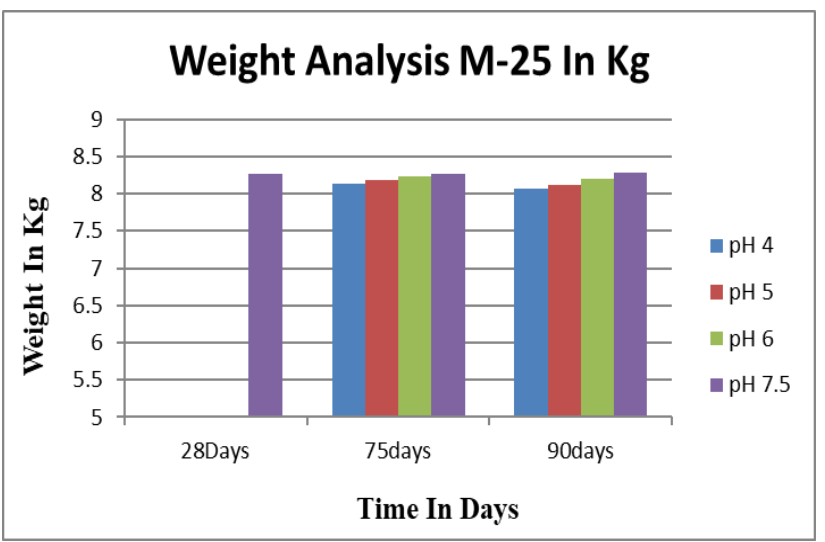

Figure 4 weight analysis $M-25$

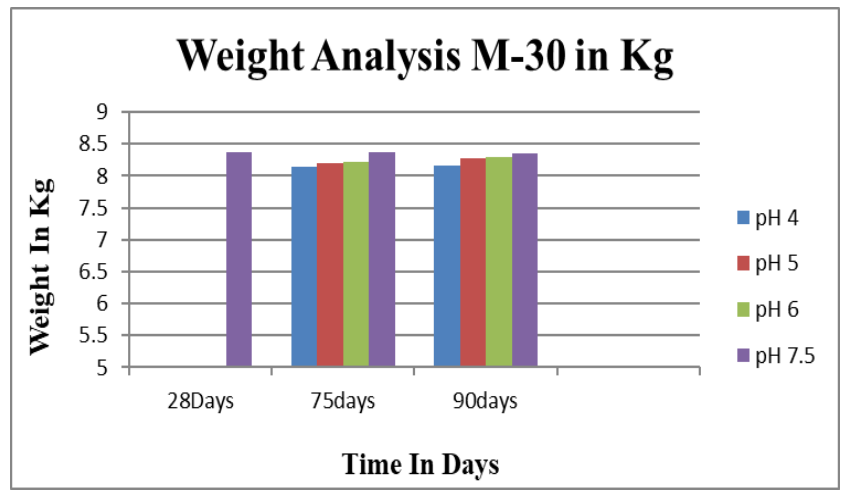

Figure 5 weight analysis M-30

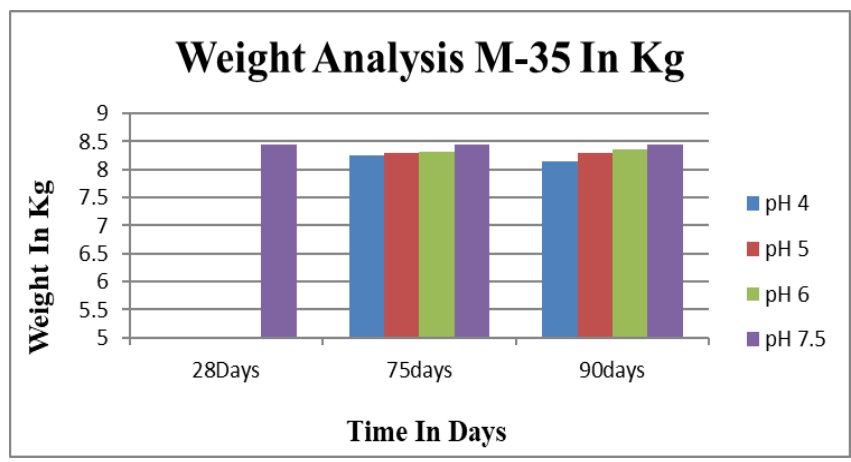

Figure 6 weight analysis M-35

The effect of concrete grade M-25 and sulphate dosages on the weight loss of concrete mixes after 75days and 90days of pH4.0, pH5.0 and pH6.0 sulphate exposure is shown in above figures. From these figures it is observed that M-25 concrete grade has a noticeable effect on weight loss of concrete subjected to pH4.0, pH5.0 and pH6.0 sulphate attack. The weight loss after 75 days is $1.7 \%, 1 \%$ and $.5 \%$ with pH4.0, pH5.0 and pH6.0 respectively. The reduction in weight after 90days of exposure is $2.4 \%, 1.9 \%$ and $.9 \%$ with $\mathrm{pH} 4.0$, pH5.0 and pH6.0 respectively. In M-30 the reduction in weight after 75 days is $2.7 \%, 2 \%$ and $1.8 \%$ with pH4.0, pH5.0 and pH6.0 respectively. The weight loss after 90days of exposure is $2.4 \%, 1.1 \%$ and .8\% with $\mathrm{pH} 4.0$, pH5.0 and pH6.0 respectively. Similarly for M-35 the reduction in weight after 75 days is $2.3 \%, 1.7 \%$ and $1.5 \%$ with $\mathrm{pH} 4.0, \mathrm{pH} 5.0$ and $\mathrm{pH} 6.0$ respectively. The reduction in weight after 90days of exposure is 3.5\%, 1.8\% and 1\% with pH4.0, pH5.0 and pH6.0 respectively.

\subsection{Density analysis}

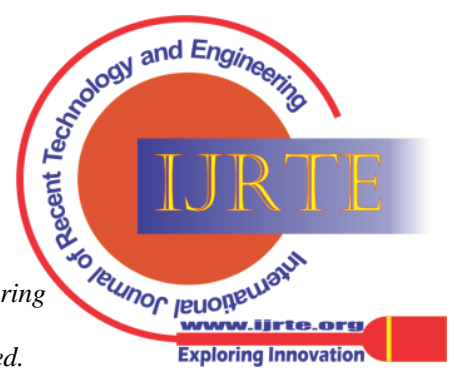


The Effect of Sulfate Attack on Physical Properties of Concrete

Table 6 density analysis

\begin{tabular}{|c|c|c|c|c|c|c|c|c|c|c|}
\hline \multirow[t]{3}{*}{ s.no. } & \multirow{3}{*}{$\begin{array}{c}\mathrm{pH} \\
\text { value }\end{array}$} & \multicolumn{9}{|c|}{ Density analysis in $\mathrm{kg} / \mathrm{m}^{3}$} \\
\hline & & \multicolumn{3}{|c|}{ M-25 grade of concrete } & \multicolumn{3}{|c|}{ M-30 grade of concrete } & \multicolumn{3}{|c|}{ M-35 grade of concrete } \\
\hline & & 28days & 75days & 90days & 28days & 75days & 90days & 28days & 75days & 90days \\
\hline 1 & 4 & - & 245.30 & 249.59 & - & 251.66 & 252.31 & - & 254.94 & 251.79 \\
\hline 2 & 5 & - & 253.09 & 250.86 & - & 253.43 & 255.81 & - & 256.58 & 256.24 \\
\hline 3 & 6 & - & 254.20 & 253.55 & - & 253.95 & 256.40 & - & 257.01 & 258.31 \\
\hline 4 & 7.5 & 255.50 & 255.75 & 255.87 & 258.53 & 258.65 & 258.41 & 261.00 & 261.06 & 261.13 \\
\hline
\end{tabular}

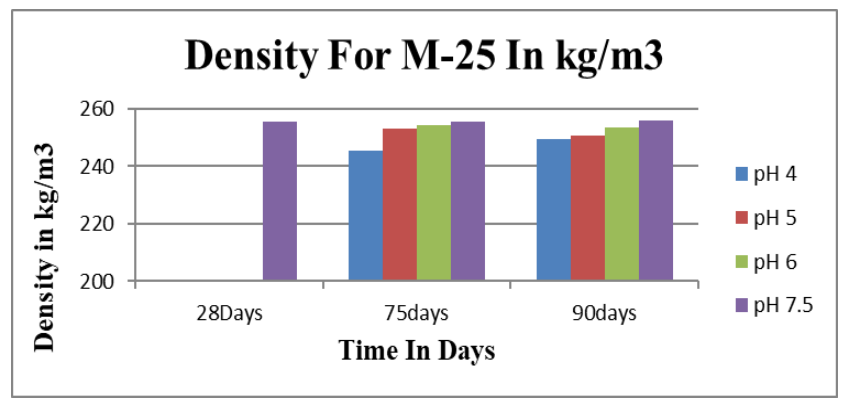

Figure 7 density for M-25

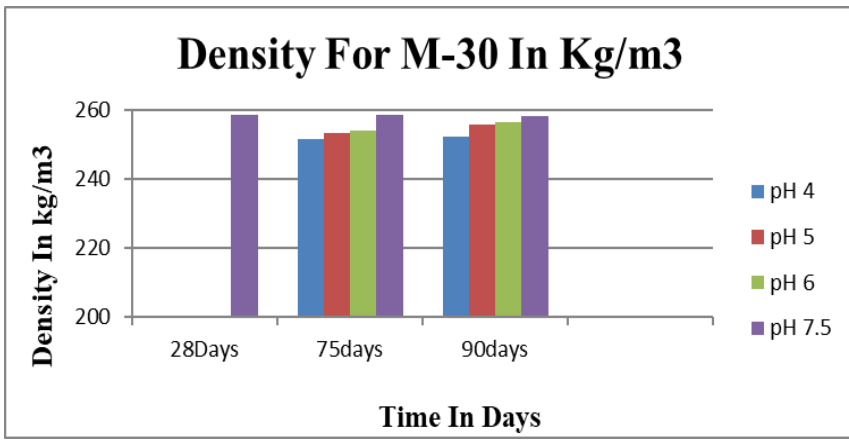

Figure 8 density for M-30

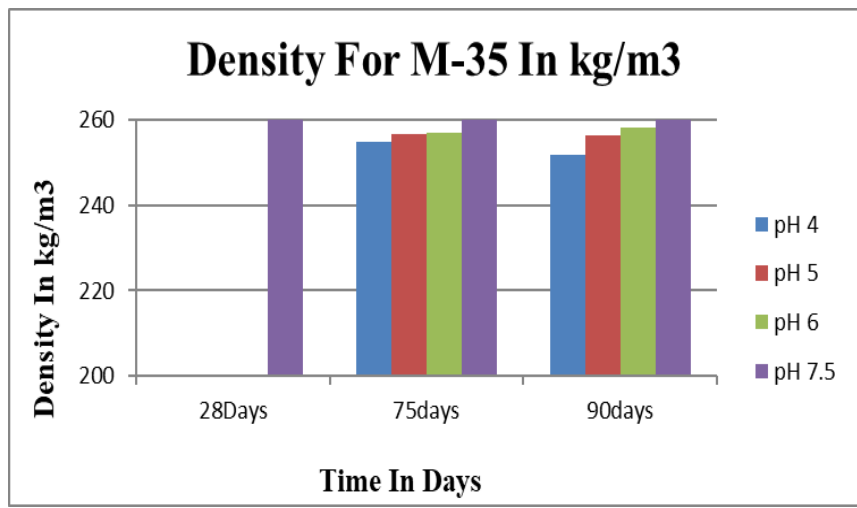

Figure 9 density for M-35

The mass change of concrete cube fully immersed in the sulphate solution was monitored on $75^{\text {th }}$ day and $90^{\text {th }}$ day. Before measuring their mass, all concrete cubes were airdried in the laboratory at room temperature. Figures showed the density loss on 75days and 90days exposure of sulphate.

\subsection{Flexural strength tests}

Table 7 Flexural strength at 90days

\begin{tabular}{|c|c|c|c|c|}
\hline pH value & 4.0 & 5.0 & 6.0 & 7.5 \\
\hline M-25 & 3.37 & 3.60 & 3.93 & 4.36 \\
\hline M-30 & 3.91 & 4.24 & 4.41 & 4.72 \\
\hline M-35 & 3.92 & 4.29 & 4.76 & 5.20 \\
\hline
\end{tabular}

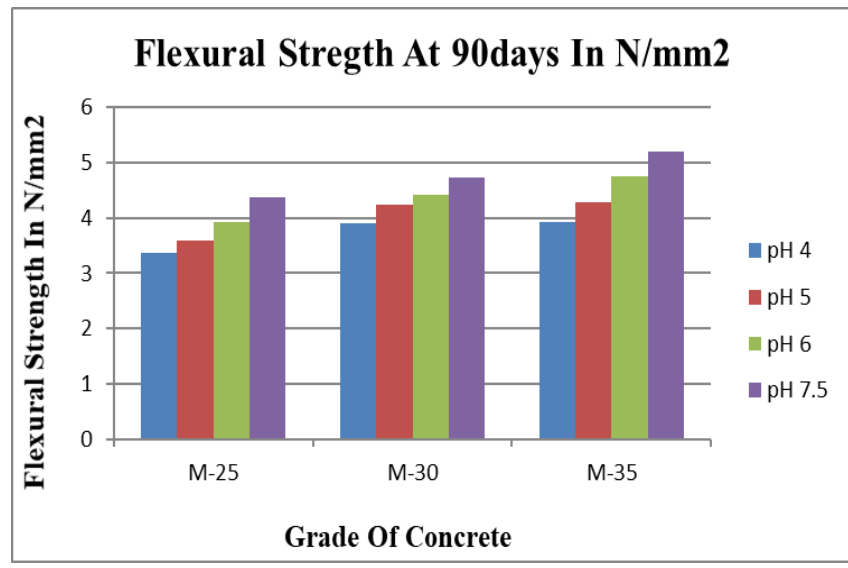

Figure 10 flexural strength

Figure chart above is showing the flexural strength losses of concrete grades with sulphate concentration, determined after 90days of pH4.0, pH5.0 and pH6.0 sulphate exposure. The test results have clearly shown that using different dosages of sodium sulphate have a positive effect on the decrease of flexural strength loss compared with that of control mix. For example, for M-35 concrete grade mix with sulphate, the reduction in flexural strength after 90days of exposure is 25\%, $17.5 \%$ and $8.5 \%$ with pH4.0, pH5.0 and pH6.0 respectively.

\subsection{Weight analysis of beam}

Table 8 Weight analysis of beam after 90days

\begin{tabular}{|c|c|c|c|c|}
\hline pH value & 4.0 & 5.0 & 6.0 & 7.5 \\
\hline M-25 & 12.140 & 12.200 & 12.260 & 12.280 \\
\hline M-30 & 12.370 & 12.410 & 12.420 & 12.460 \\
\hline M-35 & 12.470 & 12.640 & 12.730 & 12.960 \\
\hline
\end{tabular}

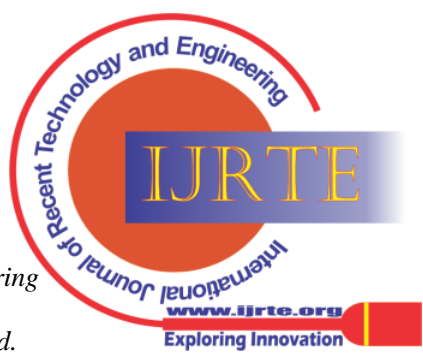




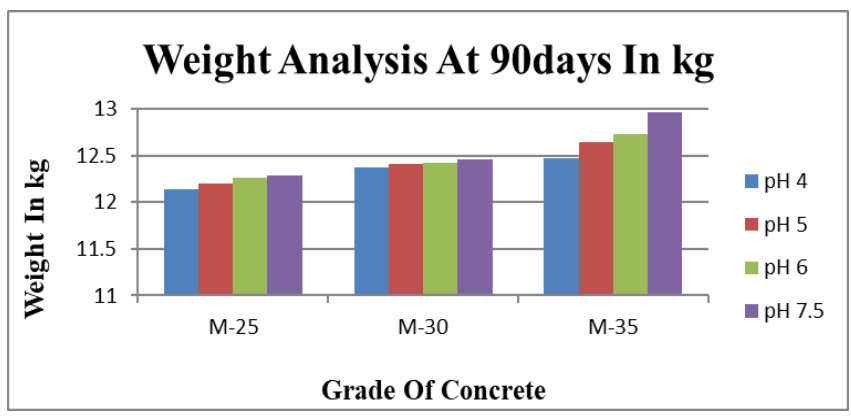

Figure 11 weight analysis of beam

The effect of sulphate dosages on the weight loss of concrete mixes after 90days at pH4.0, pH5.0 and pH6.0 sulphate exposure is shown in figures. From these figures it is observed that concrete grade has a noticeable effect on weight loss of concrete subjected to pH4.0, pH5.0 and pH6.0 sulphate attack.

\subsection{Visual Appearances}

\subsubsection{Visual Appearance at 75days}

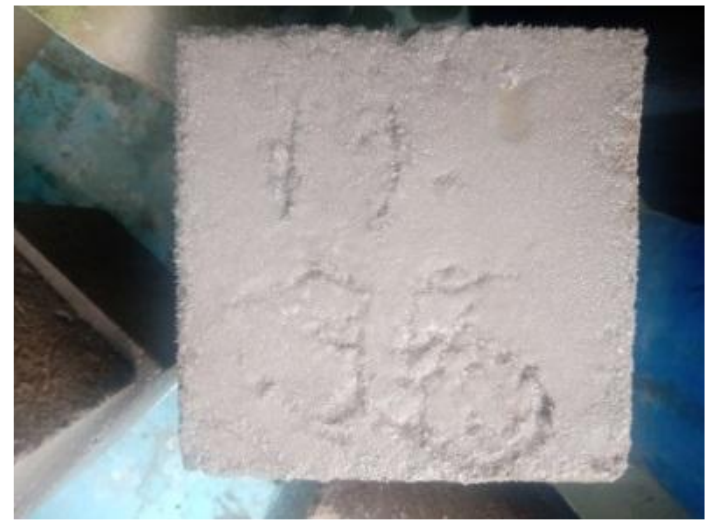

At pH 4.0

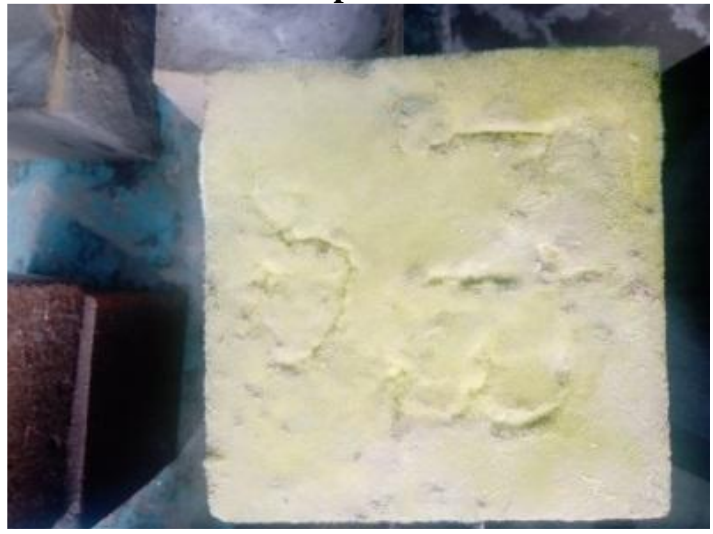

At pH 5.0

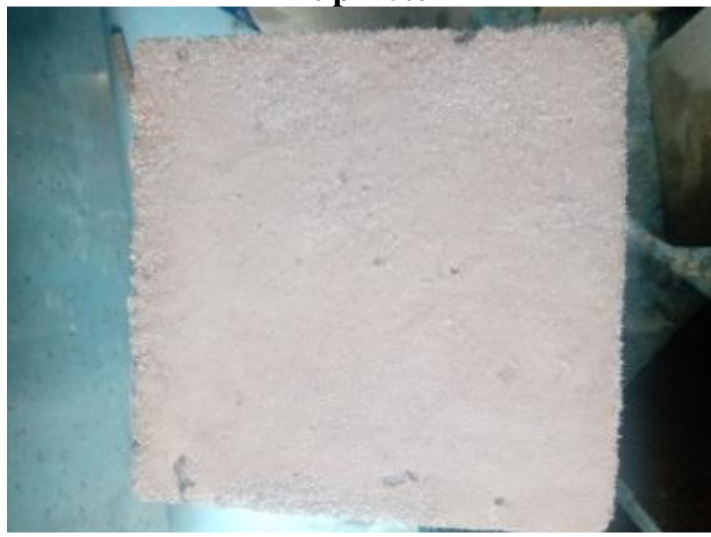

At pH 6.0

Retrieval Number: 100.1/ijrte.B60920710221

DOI: 10.35940/ijrte.B6092.0710221

Journal Website: www.ijrte.org
A Discoloration appearing to be green in color was seen on the concrete blocks when left immersed in sulphate solution ( $\mathrm{pH} 4.0$ ) for 75days. The discoloration was light pink color at $\mathrm{pH}$ 5.0, off white colour at pH 6.0.

\subsubsection{Visual Appearance after 90days}

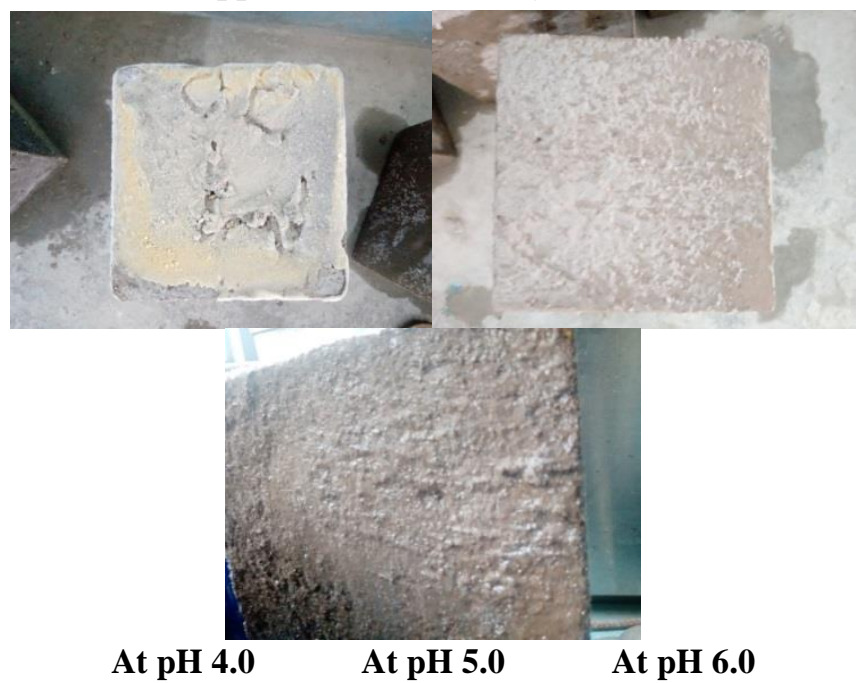

Discoloration of green color $(4.0 \mathrm{pH})$, light pink color $(5.0 \mathrm{pH})$ and off white colour $(\mathrm{pH} 6.0)$ was observed on the concrete blocks when left immersed in sulphate solution for 90days. It appeared like flakes of concrete and resembled like mold growth.

\section{CONCLUSION}

Based on the results obtained from this study, the following can be concluded:

- The compressive strength losses of M-25 concrete grade with sulphate concentration, determined after 75days and 90days at pH4.0, pH5.0 and pH6.0 sulphate exposure is given as under:-

The compressive strength loss after 75days of exposure is $11.2 \%, 10.20 \%$ and $8 \%$ with $\mathrm{pH} 4.0$, pH5.0 and pH6.0 respectively. The compressive strength loss after 90days of exposure is $14.8 \%$, $12.34 \%$ and $8.6 \%$ with $\mathrm{pH} 4.0$, pH5.0 and pH6.0 respectively.

- The compressive strength losses of M-30 concrete grade with sulphate concentration, determined after 75days and 90days of pH4.0, pH5.0 and pH6.0 sulphate exposure is given as under:-

The reduction in compressive strength after 75 days of exposure is $8.1 \%, 6 \%$ and $3.8 \%$ with $\mathrm{pH} 4.0$, pH5.0 and pH6.0 respectively. The reduction in compressive strength after 90days of exposure is 13.6\%, 9\% and 6\% with pH4.0, pH5.0 and pH6.0 respectively.

- The compressive strength losses of M-35 concrete grade with sulphate concentration, determined after 75days and 90days of pH4.0, pH5.0 and pH6.0 sulphate exposure is given as under:

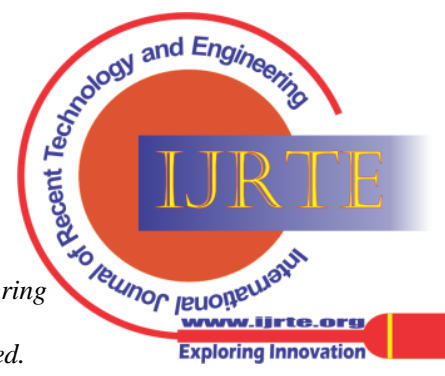


The reduction in compressive strength after 75days of exposure is $7.1 \%, 3 \%$ and $2.1 \%$ with $\mathrm{pH} 4.0$, pH5.0 and pH6.0 respectively. The compressive strength loss after 90days of exposure is $11.7 \%, 63 \%$ and $4.8 \%$ with pH4.0, pH5.0 and pH6.0 respectively.

- From the above results it can be concluded that from the compressive strength point of view, the loss of compressive strength reduces as concrete grade is increased from M-25 to M-35. The test results of weight loss and density loss also confirm the same.

- Discoloration of concrete was observed on the concrete blocks when left immersed in sulphate solution (pH 4.0, $\mathrm{pH} 5.0$ and $\mathrm{pH}$ 6.0) for 75days and 90days. It appeared like flakes of concrete and resembled like mold growth.

\section{ACKNOWLEDGEMENT}

I would like to extend profound gratitude and respect to my Project Guide Mr. Rajiv Banerjee and Mr. Syed Ashraf Hussain for their timely and continual support. The technical advice tendered by the two gentlemen was extremely useful in timely completion of the project. Their support was a source of inspiration and encouragement. It gave me enough confidence to see through the difficulties encountered during the execution of the project in Covid Period.

\section{REFERENCES}

\section{IS Code:}

Mix design: IS10262-2019, Aggregate: IS 383- 2016, Cement: IS 4013- 2019, Admixture: IS 9103- 1999, ACT Test: IS9013- 1978, Flexural strength: IS516-2018

\section{Journals:}

1. Xing Jiang et.al Effect of temperature on durability of cement-based material to physical sulfate attack https://doi.org/10.1016/j.conbuildmat.2020.120936

2. Fang Liu et.al External sulfate attack on concrete under combined effects of flexural fatigue loading and drying-wetting cycles https://doi.org/10.1016/j.conbuildmat.2020.118224

3. Davood Mostofinejad et.al Durability of concrete containing recycled concrete coarse and fine aggregates and milled waste glass in magnesium sulfate environment https://doi.org/10.1016/j.jobe.2020.101182

4. Feng Xie et.al Experimental study on performance of cast-in-situ recycled aggregate concrete under different sulfate attack exposures https://doi.org/10.1016/j.conbuildmat.2020.119144

5. Kun Wang el.al Influence of dry-wet ratio on properties and microstructure of concrete under sulfate attack https://doi.org/10.1016/j.conbuildmat.2020.120635

6. Zhongya Zhang et.al Understanding of the deterioration characteristic of concrete exposed to external sulfate attack: Insight into mesoscopic pore structures https://doi.org/10.1016/j.conbuildmat.2020.119932

7. Juntao Dang et.al Durability and microstructural properties of concrete with recycled brick as fine aggregates http://www.sciencedirect.com/science/journal/09500618

8. Syed Minhaj Saleem Kazmi et.al Effect of recycled aggregate treatment techniques on the durability of concrete: A comparative evaluation http://www.sciencedirect.com/science/journal/09500618

9. D. Ambika et.al An exploration on the durability properties of reactive powder concrete http://www.sciencedirect.com/science/journal/22147853

10. Kirill Shuldyakov et.al Stable microstructure of hardened cement paste - A guarantee of the durability of concrete http://www.sciencedirect.com/science/journal/22145095

11. Tengjiao Wang et.al Experimental study on the effect of carbon nanofiber content on the durability of concrete http://www.sciencedirect.com/science/journal/09500618

12. Pinghua Zhu et.al Durability evaluation of recycled aggregate concrete in a complex environment https://doi.org/10.1016/j.jclepro.2020.122569
13. Peng Liu et.al Effect of sulfate solution concentration on the deterioration mechanism and physical properties of concrete https://doi.org/10.1016/j.conbuildmat.2019.08.022

14. Ying Chen et.al Effect of sulfate solution concentration on the deterioration mechanism and physical properties of concrete https://doi.org/10.1016/j.conbuildmat.2019.08.022

15. Feng Xu et.al Experimental investigation on the effect of sulfate attack on chloride diffusivity of cracked concrete subjected to composite http://www.sciencedirect.com/science/journal/09500618

16. Ramasamy Gopalakrishnan et.al The effects on durability and mechanical properties of multiple nano and micro additive OPC mortar exposed to combined chloride and sulfate attack https://doi.org/10.1016/j.mssp.2019.104772

17. Renan P. Salvador et.al Influence of accelerator type and dosage on the durability of wet-mixed sprayed concrete against external sulfate attack http://www.sciencedirect.com/science/journal/09500618

18. Ahmed M. Diab et.al Effect of nanomaterials additives on performance of concrete resistance against magnesium sulfate and acids https://doi.org/10.1016/j.conbuildmat.2019.03.099

19. Jianwei Sun et.al Influences of limestone powder on the resistance of concretes to the chloride ion penetration and sulfate attack http://www.sciencedirect.com/science/journal/

20. Zanqun Liu et.al Effect of carbonation on physical sulfate attack on concrete by

$\mathrm{Na} 2 \mathrm{SO} 4$ https://doi.org/10.1016/j.conbuildmat.2018.10.191

21. Rim Ragoug et.al Durability of cement pastes exposed to external sulfate attack and leaching: Physical and chemical aspects https://doi.org/10.1016/j.cemconres.2018.11.006

22. Tiejun Liu et.al Experimental investigation on the durability performances of concrete using cathode ray tube glass as fine aggregate under chloride ion penetration or sulfate attack http://www.elsevier.com/locate/conbuildmat

23. Dezhi Wang et.al Durability of concrete containing fly ash and silica fume against combined freezing-thawing and sulfate attack http://dx.doi.org/10.1016/j.conbuildmat.2017.04.172

24. Mohammed Fatah Lakhdari et.al Combined Effect of Temperature and Sulfate Attack on the Durability of Repair Mortar Based on Mixture of Dune-Alluvial Sand http://www.sciencedirect.com/

25. A.R. Suleiman et.al Effect of surface treatment on durability of concrete exposed to physical sulfate attack http://dx.doi.org/10.1016/j.conbuildmat.2014.10.006

\section{AUTHORS PROFILE}

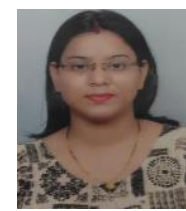

Pooja Kanaujia, is currently pursuing M.Tech (Structural Engineering) from integral university, Lucknow, India. She did b.tech (civil engineering) in 2014 from kamla nehru institute of physical and social sciences, sultanpur, India.

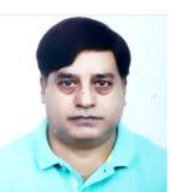

Rajiv Banerjee, is currently pursuing Ph.D from Dr A.P.J. Abdul Kamal Technical University, Lucknow, India. he did his b.tech in 1984from institute of technology, banaras hindu university(now IIT-BHU), varanasi and M.E. from all india institute of public health \& hygiene, Kolkata. he has worked in municipal engineering directorate, gov. of west bengal in capacity as an assistan engineer and executive engineer for 24years. he also worked as consulting engineer in school service commission, gov. of west bengal. he has served in gannon dunker lay ltd. \& company as an engineer. he has an industry experience of 27 years as well as an academic experience of 10 years. he is a member of institute of engineers, India.

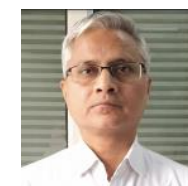

Syed Mohammad Ashraf Husain, was completed civil engineering (diploma) in 1990 and worked on several construction projects not only in India but also overseas upto 2007 almost 17years. he completed his b.tech in 2011 and m.tech (structural engineering) in 2014. He has been associated with integral university for las 7years as assistant professor and have been guided several projects and m.tech dissertation.

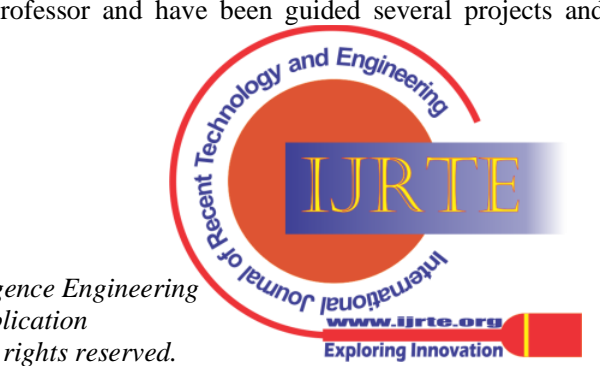

Blue Eyes Intelligence Engineering and Sciences Publication 


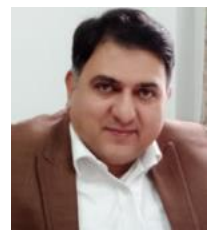

Sabih Ahmad, received his b.sc engineering (civil) from A.M.U, in 1994. In 2002 he received his Master's degree in building engineering from A.M.U, Aligarh, and Ph.D. in civil Engineering in 2018 from integral university, lucknow. He has a vide experience in teaching, research at UG and PG levels. presently he is associate professor and former head of the department of civil engineering at integral university, lucknow. In addition, he has been awarded the research excellence award (2017) for his research work in the field of soil engineering. He has authored numerous research papers in national and international journals/conferences. He is also a member of the Institution of Engineers as well as the Geotechnical Society (Delhi chapter). Also four research scholars are pursuing Ph.D under his guidance.

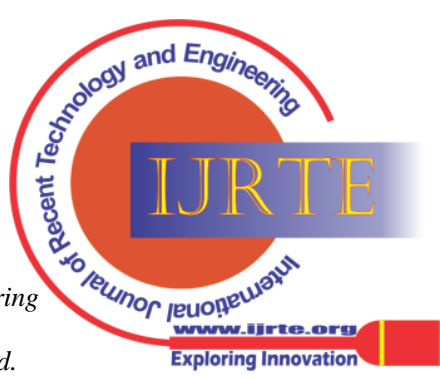

